\title{
Research of dumps at construction sites in the urban area
}

\author{
Yu. Galitskova \\ Samara State University of Architecture and Civil Engineering
}

\begin{abstract}
The article deals with the problems of the construction waste formed in the course of demolition and construction of buildings in the city. The author presents results of the survey made at construction sites located on the territory of Samara, gives the analysis of the construction waste composition and considers options for the use of the construction waste as a secondary resource in the manufacture of building materials.
\end{abstract}

Keywords: construction waste, environmental pollution, urban development, recycling.

\section{INTRODUCTION}

The urban environment is constantly evolving and being transformed. The changes are expressed not only in the reconstruction of buildings, but also in the demolition of obsolete structures and construction of new ones. Construction and demolition are always accompanied by the formation of large amounts of waste. Depending on the type of demolition or construction different kinds of waste are formed: broken concrete, crushed brick, wood waste, etc. Usually the formed waste is temporarily stored directly at construction sites and as it is accumulated it is removed for processing or to specialized dump sites.

Construction waste has a negative environmental impact both during demolition and during accumulation at the areas of temporary storage. With time under the action of wind and rain there is a gradual destruction of waste and its spread over the construction site and the adjacent area [1].

\section{MATERIALS AND METHODS}

In 2014 a group of students of the Samara State University of Architecture and Civil Engineering under the guidance of the author examined the existing construction sites in Samara. The location inspection paid special attention to compliance of construction sites with the sanitary requirements and determination of waste composition. The following types of waste were distinguished: broken concrete products, crushed brick, and scraps of metal, wood waste, plastics, glass, paper and paperboard.

As many as 12 construction sites have been examined [2-4]. All sites were located in close proximity to residential areas in the central part of the city. Figure 1 shows the scheme of one of the construction sites.

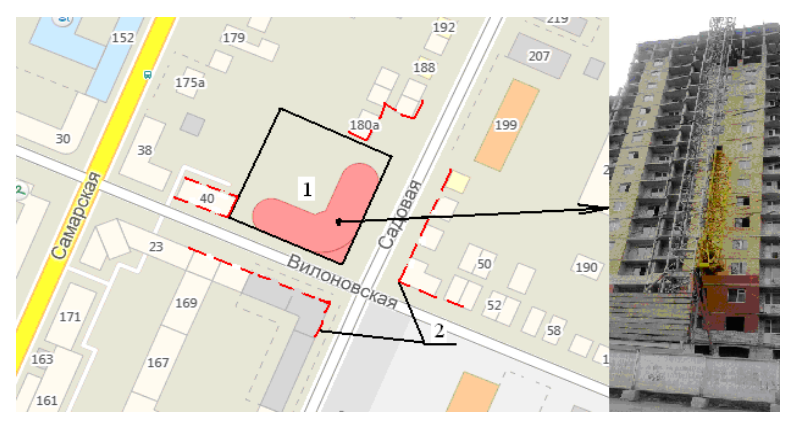

Fig. 1. The scheme of construction site №1: 1 - the construction site, 2 - borders of a residential area

TABLE 1. Characteristics of construction sites

\begin{tabular}{|c|l|c|c|c|c|}
\hline № & $\begin{array}{c}\text { Construction } \\
\text { site location }\end{array}$ & $\begin{array}{c}\text { Building } \\
\text { type }\end{array}$ & $\begin{array}{c}\text { A } \\
\text { number } \\
\text { of } \\
\text { floors }\end{array}$ & $\begin{array}{c}\text { Distance } \\
\text { from the } \\
\text { residential } \\
\text { area, m }\end{array}$ & $\begin{array}{c}\text { Type of } \\
\text { the } \\
\text { adjacent } \\
\text { residential } \\
\text { area }\end{array}$ \\
\hline 1 & $\begin{array}{l}\text { Vilonovskaya } \\
\text { St./Sadovaya St. }\end{array}$ & $\begin{array}{c}\text { Monolithic } \\
\text { reinforced } \\
\text { concrete }\end{array}$ & $28-34$ & 10 & private \\
\hline 2 & Sadovaya St. & $\begin{array}{c}\text { Monolithic } \\
\text { reinforced } \\
\text { concrete }\end{array}$ & 9 & 10 & private \\
\hline 3 & Leninskaya St. & $\begin{array}{c}\text { Monolithic } \\
\text { reinforced } \\
\text { concrete }\end{array}$ & 17 & 15 & private \\
\hline 4 & $\begin{array}{l}\text { Polevaya St./ } \\
\text { Leninakaya St. }\end{array}$ & $\begin{array}{c}\text { Monolithic } \\
\text { reinforced } \\
\text { concrete }\end{array}$ & 17 & 30 & high rise \\
\hline 5 & Petlevaya St. & $\begin{array}{c}\text { Monolithic } \\
\text { reinforced } \\
\text { concrete }\end{array}$ & 24 & 35 & private \\
\hline 6 & Vrubelya St. & $\begin{array}{c}\text { Frame, } \\
\text { administra- } \\
\text { tive }\end{array}$ & 2 & 86 & high rise \\
\hline 8 & Solnechnaya St. & Panel & $19-24$ & 100 & high rise \\
\hline 9 & $5^{\text {th }}$ Proseka & Panel & 18 & 25 & high rise \\
\hline 10 & $5^{\text {th }}$ proseka & Panel & 19 & 40 & high rise \\
\hline 11 & $5^{\text {th }}$ proseka & Brick & 9 & 95 & high rise \\
\hline 12 & $5^{\text {th }}$ proseka & Panel & 25 & 90 & high rise \\
\hline
\end{tabular}

ISSN 1691-5402 
Characteristics of construction sites are given in Table 1. The location inspection was carried out twice: in spring and autumn. The time interval between surveys was at least 4 months.

The first stage of the studies showed the absence at almost all construction sites specially equipped places for temporary storage of waste. The waste was placed in spontaneously formed open dump sites and represented chaotically piled and mixed waste. Besides, all dump sites were found to be compact, i. e. they occupied a small area at the construction site and had an average height of about $1-1,5 \mathrm{~m}$. Then the wastes composition of a dump site was defined. The wastes were sorted according to their main elements and a ratio of their volume shares to the whole of the dump site was calculated.

The composition of the dump site showed that the main components of the construction waste in the examined dump sites (fig.2) were as follows: broken concrete, wood waste, scraps of metal and polymers

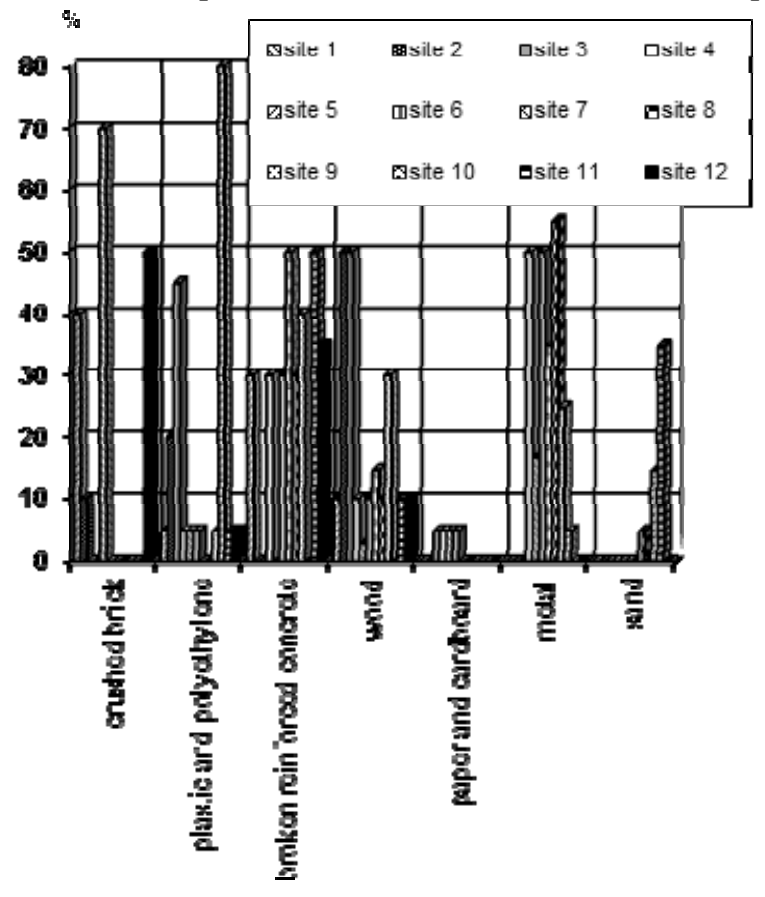

Figure 2. The composition of construction waste dump sites

At construction site №5 the maximum amount of waste (about 70\%) was crushed brick. It was explained by the basic material used in the construction of a building at this site. At construction site №10 the maximum waste components were polymers $(80 \%)$, as the construction company had completed the main stage of the building construction and went to work on the interior decoration, which was accompanied by the formation of a large number of plastic containers.

The most rare components were rags in the amount of $15 \%$ (bags for loose materials) found at the dump site of site №1, paper waste and paperboard in the amount not exceeding $5 \%$ of the total volume of the construction waste (dump sites №3 - 6) and a roofing felt waste in the amount of $15 \%$ (construction site №2).

In October- November 2014 the same construction sites were examined once again. Analysis of the obtained data showed that no construction waste was available at $60 \%$ of all urban building sites, which was associated primarily with the transition of those companies to the final stage of construction, i.e. layout and landscaping. The period of time of temporary dump sites was about one year.

The remaining $40 \%$ of the sites had territories without significant changes, i.e. open construction waste dump sites had not been removed (fig.3). At two sites there had been a slight increase in waste; at one of them to the list of previously defined waste the foam plastic was added.

\section{RESULTS AND DISCUSSION}

During prolonged storage the construction waste begins to undergo qualitative changes. For example, the concrete and reinforced concrete can have a gradual destruction of the weak surface layer under the adverse effects of rain and surface runoffs formed on-site which causes the accumulation of all kinds of smaller particles (including the concrete aggregate) and concrete dust on the soil surface. Bricks are also subjected to gradual destruction and crumbing. In the case of a long stay of the metal waste in the aquatic environment (in the rain, in the lower parts where puddles form) corrosion processes occur. Prolonged 
storage of wood, cardboard and paper waste in dump sites can lead to putrefactive processes.

In addition, the close location of the residential area, particularly the private sector, to the construction site and the lack of control over the state of the site and timely removal of waste, lead, as a rule, to the transformation of the construction waste dump site into a mixed one due to the ingress of solid waste from construction workers and the surrounding residential area [5-8].

To reduce the negative impact of the construction waste on the environment a variety of ways have been developed, e. g. [9-15]. These methods allow minimizing the impact of the construction work both during dismantling obsolete buildings and during erecting new facilities. Implementation of various additional devices for environmental protection and the implementation of environmental protection measures will reduce the likelihood of soluble pollutants and dust particles in the surface layers of the soil, reduce the area of contamination by fine particles and soluble contaminants of surface flows, prevent the spread of fragments of animal waste, as well as keep the ground water and adjacent water bodies clear of polluted runoffs.

A larger amount of construction waste is normally disposed of at specialized dump sites. As this takes place, valuable components that can be used as secondary resources are lost [16-17]. The experience of foreign and some domestic enterprises shows that the processing and use of waste can save a considerable part of natural resources and make it possible to gain an additional profit. Construction wastes are ones of the most common wastes that are used in the construction process and in the process of manufacturing building materials.

For example, the metal waste is processed in areas of the country from $35 \%$ to $70 \%$, however, the metal waste formed at the construction site is almost completely disposed of at specialized dump sites. Given that the dump site metal waste ranges from 5\% to $55 \%$ in the volume and the average volume of the construction waste dump site ranges about $10 \mathrm{~m} 3$, we can say that when the bulk density of the lump scrap is $2,5-3,5 \mathrm{t} / \mathrm{m}^{3}$ and the cost of scrap is 12 rubles per kilogram it is possible to get income in the amount of up to 200000 rubles without any pre- processing.

The most common way of wood waste recycling is the processing and production of chipboards and fireboards. It can also be used directly at the construction site when installing a formwork system. Crushed brick despite its lower strength in comparison with concrete is often used when laying roads and aligning surfaces. It is used as filling when establishing drainage systems, as well as an aggregate in concrete products.

The broken concrete and reinforced concrete products accounting for from $30 \%$ to $50 \%$ in the surveyed dump sites after preliminary sorting, separation of metal and crushing are used when laying temporary roads, in preparation for the construction of permanent roads, as an aggregate in the process of production of new concrete products and so on [1820]. To improve the efficiency and increase the use of construction waste as secondary resources it is necessary to conduct a preliminary sorting of waste formed in-situ, i.e. directly on the site.

One of the possible cases for the concrete and reinforced concrete waste use is using it during the construction and reconstruction of environmental and hydraulic structures [21-23]. Since such constructions usually involve temporary or permanent contacts with water bodies, the waste used in them must undergo a thorough pre-sorting and checking for harmful pollutants.

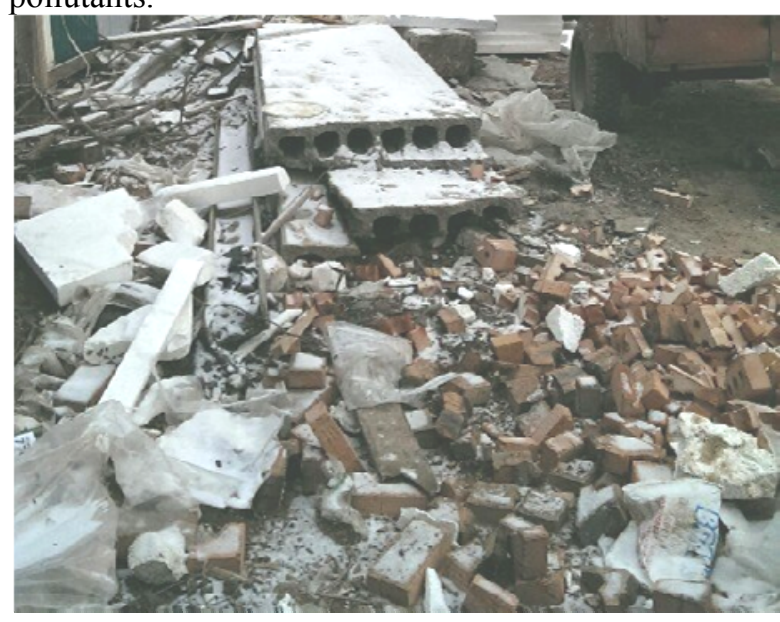

Figure 3. The view of the construction waste dump site (dump site 2)

The use of the broken concrete and reinforced concrete will reduce the amount of primary raw materials for construction, reduce the amount of waste recycled at dump sites making them long-lived and cut the negative impact on the environment.

\section{CONCLUSIONS}

1. During in-situ survey of Samara construction sites building wastes dumps were found out.The life time of these dumps is limited by the terms of construction works and can last from 1 to 7 years so it is hardly possible for them to get mature and grow into brownfields. On completion of construction the dumps are liquidated and the wastes are transported to landfills. According to the results of these examinations weight shares of their components were determined. Broken brick, timber, broken concrete and reinforced concrete as well as metals constitute a major part of it.

2. It is recommended that construction wastes be used as secondary resources in the construction work and manufacture of building materials. Some ways of 
secondary use of wastes applied nowadays in Russia and other countries are considered. It is also proposed to apply them to repair or reconstruct environmental facilities and construct flood-control dams. Such use allows not only saving the amounts of natural resources used in construction but also it leads to reduction of the wastes taken out to landfills.

\section{REFERENCES}

[1] S.S. Kakhramanova. Problema of promyshlennykh i bytovykh otkhodov na urbanizirovannykh territoriyakh Apsheronskogo poluostrova (Problems of industrial and communal wastes at urbanized territories of the Apsheron Peninsula) // Architecture and Modern Information Technologies. 2013. № 1 (22). pp. 3.

[2] Ju. M. Galitskova. Rezultat obsledovanija stroitelnoj ploshhadki, raspolozhennoj na ulice Petlevaja goroda Samara (Survey of the construction site in Samara, Petlevatya St.) // Materialy Mezhdunarodnoj nauchno-tehnicheskoj konferencii: Prirodoohrannye I gidrotehnicheskie sooruzhenija: problemy stroitelstva, ekspluatacii, ekologii i podgotovki specialistov. Samara: SGASU. 2014, pp. 154-158.

[3] Ju. M. Galitskova. Rezultat obsledovanija stroitelnoj ploshhadki, raspolozhennoj na ulice Sadovoj goroda Samara (Survey of the construction site in Samara, Sadovaya St.)// Materialy Mezhdunarodnoj nauchno-tehnicheskoj konferencii: Prirodoohrannye I gidrotehnicheskie sooruzhenija: problemy stroitelstva, ekspluatacii, ekologii I podgotovki specialistov.Samara: SGASU.2014. Pp. 159-163.

[4] Ju.M. Galitskova. Osnovnye napravlenija ispolzovanija stroitelnykh othodov ot demontazha zdanij (Main ways of use of construction waste from demolition) // Materialy Mezhdunarodnoj nauchno-tehnicheskoj konferencii: Prirodoohrannye i gidrotehnicheskie sooruzhenija: problemy stroitelstva, ekspluatacii, ekologii i podgotovki specialistov.Samara: SGASU.2014. Pp. 125-129.

[5] V.A. Shabanov, M.I. Balzannikov and Ju.M. Galitskova. Vlijanie neobustroennykh gorodskikh svalok na okruzhajushchuju sredu (Impact of open urban dumps on the environment) // Ekologija I promyshlennost Rossii. 2009. № 4. Pp. 38-41.

[6] Ju.M. Galitskova. Ob ekologicheskikh problemakh pri zastrojke gorodov (On environmental issues in the development of cities)// Nauchnoe obozrenie. 2014. № 9 (3). Pp. 798-802.

[7] T.O. Kondratenko and A.V. Sajbel. Otsenka vozdejstvija stroitelnogo proizvodstva na okruzhajushchuju sredu (Assessment of the impact of the construction industry on the environment) // Inzhenernyj vestnik Dona. 2012. T. 23. № 4-2 (23). Pp. 153.

[8] E.I. Soroka. O vlijanii othodov proizvodstva i potreblenija na okruzhajushchuju sredu i zdorovje naselenija (On the impact of the waste of production and consumption on the environment and human health) // Zdorovje. Meditsinskaja ekologija. Nauka. 2010. T. 41-42. № 1-2. Pp. 105-107.

[9] M.I. Balzannikov, A.A. Bolotova. Sposob zashchity vodoema ot zagrjaznenija (The way to protect a water body from contamination) / Patent na izobretenie RUS 2392375 10.07.2008.

[10]D. Venosta. Impact sur l'environnement, elimination e trecyclage des materiaux plastiques après usage. Corrado. Plasticulture.1999, № 117. Pp.19-24.
[11]R. Bendere, I. Donina. Solid waste management strategies the implementation of new solid waste systems / // Wspolpr. Eur.: 2 Miedzynar. forum gosp. odpadami, Poznan, 25-28 maja, 1997: Mater. forum. - Poznan, 1997. Pp. 87-102.

[12] Sui T. Use of industrial wastes in cement industry of China // ALITinform: Cement. Concrete. Dry Mixes. 2012. № 6. Pp. 615.

[13]E. Rogoś, A. Zbrowski. Perspectives for development of systems for environmental safety // Bezpieczenstwo I Technika Pozarnicza. 2010. T. 20. pp. 47-58.

[14] Waste reduction, reuse and recycling / Environ. Hong Kong, 1994: Rev., 1993/ Hong Kong, 1994.

[15]P. Ogrodnik, B. Zegardło, A. Halicka. Preliminary assessment of utilization of sanitary ceramics wastes as an aggregate in concrete working at the high temperature // Bezpieczenstwo I Technika Pozarnicza. 2012. T. 25. Pp. 49-56.

[16]A.N. Protopopov. Stroitel'nye materially kak product pererabotki otkhodov stroitelnogo proizvodstva (Building materials as a product of the construction waste recycling) // Stroitel'nye materialy. 2003. № 4. Pp. 29-30.

[17]E.S. Shirinkina, I.N. Shvecova and G.M. Batrakova. Resursnyj potencial otkhodov demontazha isnosa zdanij I sooruzhenij promyshlennogo naznachenija (The resource potential of the waste from dismantling and demolition of buildings and structures for industrial purposes) // Ekologija I promyshlennost' Rossii. 2011. № 5. Pp. 48-51.

[18]A.A. Kalgin, M.A.Fakhratov and V.I. Sohrjakov. Opyt ispolzovanija otkhodov droblenogo betona $\mathrm{V}$ proizvodstve betonnykh i zhelezobetonnykh izdelij (Experiences in the use of crushed concrete waste in the production of concrete and reinforced concrete products) // Stroitelnye materialy. 2010. № 6. Pp. 32-33.

[19]A.A. Borisov. O vozmozhnosti ispolzovanija dispersnykh tehnogennykh othodov $\mathrm{v}$ melkozernistykh betonakh (On the possibility of using dispersed industrial wastes in fine-grained concrete) // Stroitelnye materialy. 2004. № 8. Pp. 38-39.

[20]S.A.Ju. Murtazaev, V.H. Hadisov and M.R. Hadzhiev. Ispolzovanie keramicheskogo kirpichnogo boja dlja poluchenija legkikh keramobetonov (Use of broken ceramic brick for obtaining lightweight cementless concrete) // Ekologija i promyshlennost Rossii. 2014. № 10. Pp. 22-25.

[21]M.I. Balzannikov, Ju.M. Galitskova, V.V. Semenova. Utilizacija otkhodov proizvodstva stroitelnykh blokov s tsel'ju snizhenija zagrjaznenija okruzhajushhej sredy (Recycling of production wastes to reduce the pollution of the environment) // Materialy Mezhdunarodnoj nauchno-tekhnicheskoj konferencii: Prirodoohrannye i gidrotehnicheskie sooruzhenija: problemy stroitelstva, ekspluatacii, ekologii i podgotovki specialistov. Samara: SGASU. 2014. Pp. 61-64.

[22] Ju.M. Galitskova. Podgotovka stroitelnykh otkhodov k vtorichnomu ispolzovaniju (Preparation of construction wastes for recycling) // Materialy Mezhdunarodnoj nauchnotekhnicheskoj konferencii: Prirodookhrannye i gidrotehnicheskie sooruzhenija: problemy stroitelstva, ekspluatacii, ekologii i podgotovki specialistov. - Samara: SGASU. 2014. Pp. 130-134.

[23]Ju.M. Galitskova. Ispolzovanie stroitelnykh otkhodov dlja remonta malykh gidrotehnicheskikh objektov (The use of construction waste for repairing small water projects) // Nauchnoe obozrenie. 2014. №5. Pp. 119-123. 